\title{
VALIDATED SPECTROPHOTOMETRIC METHODS FOR SIMULTANEOUS DETERMINATION OF BRINZOLAMIDE AND TIMOLOL MALEATE IN THEIR PURE FORM AND OPHTHALMIC PREPARATION
}

\section{BY}

Maya Shaaban Eissa ${ }^{1}$, Israa Mamdouh Nour ${ }^{1}{ }^{*}$, Mohammed Refaat Elghobashy, Mostafa Abdelaty Shehata ${ }^{2}$

\section{FROM}

${ }^{1}$ Analytical ChemistryDepartment, Faculty of Pharmacy, Egyptian Russian University, Badr City, Cairo, Egypt.

${ }^{2}$ Analytical Chemistry Department, Faculty of Pharmacy, Cairo University, Kasr ElAini street, Cairo, Egypt.

\begin{abstract}
Four sensitive, simple and precise spectrophotometric methods for the simultaneous determination of brinzolamide (BRZ) and timolol maleate (TML) in their pharmaceutical formulation are developed and validated. Method A is the ratio difference spectrophotometric method (RDSM) which can measure the difference in amplitudes between 251 and $265 \mathrm{~nm}$ of ratio spectrum for brinzolamide and between 285 and $306 \mathrm{~nm}$ of ratio spectrum for timolol. Method B is the mean centering of ratio spectra method (MCR) by measuring the peak amplitude at $252 \mathrm{~nm}$ for brinzolamide and $304 \mathrm{~nm}$ for timolol. Method C is area under the curve (AUC) in which the area under the curves for brinzolamide and timolol were selected over the ranges of (260$265)$ and (282-288) $\mathrm{nm}$. Method D is the bivariate method (BVM) which depended on the quantitative evaluation of the absorbances at 265 and $285 \mathrm{~nm}$, respectively. Beer's Lambert's law for the adopted methods were obeyed over the concentration range of 6 $36 \mu \mathrm{g} / \mathrm{mL}$ for Brinzolamide and $6-42 \mu \mathrm{g} / \mathrm{mL}$ for Timolol. The obtained results were statistically compared with those obtained by the reported methods, showing no significant difference. The suggested methods were validated according to the ICH guidelines and were successfully applied for simultaneous determination of brinzolamide and timolol maleate in bulk drug and in their ophthalmic preparation.
\end{abstract}

Keywords: Brinzolamide; Timolol maleate; ratio difference; mean centering of ratio spectra; area under the curve; bivariate; spectrophotometry

*Corresponding author e-mail: Israamamdouh88@gmail .com 


\section{Introduction}

Brinzolamide (BRZ), [(R)-(+)-4-Ethylamino-2-(3-methoxypropyl)-3, 4dihydro-2H thieno [3,2-e]-1,2-thiazine-6-sulfonamide-1,1-dioxide] Fig. 1A [USP,2012], is a carbonic anhydrase inhibitor used to decrease intraocular pressure in patients with open-angle glaucoma or ocular hypertension by reducing the amount of fluid produced by the eye.

Timolol (TML), [(S)- 1-[(1,1-dimethylethyl)amino]-3-[[4-(4-morpholinyl)1,2,5-thiadiazol-3-yl]oxy]-2 propanol (Z)-2 butenedioate(1:1)] Fig. 1B [USP,2012], is a non-selective beta-adrenergic receptor antagonist used to treat glaucoma by decreasing the ocular pressure by reducing aqueous humur production through blockage of the beta receptors on the ciliary epithelium.

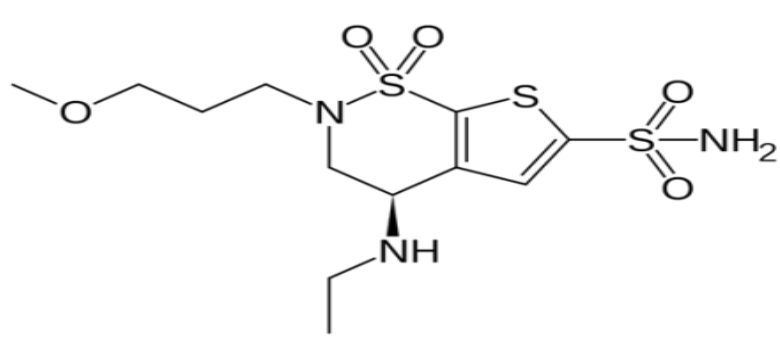

( A)<smiles>CC(C)(C)NC[C@H](O)COc1nsnc1N1CCOCC1</smiles>

(B)

Fig. (1): Chemical structure of Brinzolamide (A) and Timolol Maleate (B)

It was found that the combination of BRZ and TML gives better effect in treatment of glaucoma than each drug alone, this combination was marketed in the form of eye drops [P.A.Shah et al. 2014].

Literature survey reports that there are few analytical methods available for simultaneous estimation of BRZ and TML. Three spectrophotometric methods namely simultaneous equation method, Q-absorbance ratio method and ratio first derivative method for the simultaneous determination of BRZ and TML in their mixture form [P.A.Shah et al. 2014] and HPLC method [R.Khatun et al. 2014] were reported. In context to this, the aim of this research paper is to present four recent, sensitive, economical, precise and accurate UV spectrophotometric methods that present wide application for the simultaneous estimation of BRZ and TML in bulk drug and in their ophthalmic preparation without prior separation. Our work can be incorporated in the quality control analysis where time and coast of great value.

\section{Experimental}

\subsection{Apparatus}

JASCO dual beam (Japan) UV-visible spectrophotometer model V-630. The bundle software, spectra manager II was used. The spectral slit width was $2 \mathrm{~nm}$ and the speed of scan is $1000 \mathrm{~nm} / \mathrm{min}$.

Sonicator: Bandelin Sonorex RK 510S, Donation of Alexander von Hum-boldt - Foundation, Bonn-Bad, Godesberg, Federal Republic of Germany. 


\subsection{Software}

All computations of mean centering method were performed in Matlab® version 7.10 [Matlab 2010].

\subsection{Materials and reagents}

Methanol (Piochem®) spectroscopic grade and distilled water.

\subsection{Pure standard:}

Brinzolamide standard was purchased from Sigma-Aldrich Chemie $(\mathrm{GmbH}$, Germany) and Timolol was kindly supplied by Epico (Cairo, Egypt) ; their purity was reported to be $99.7 \%$ and $99.92 \%$, respectively according to the reported HPLC method [R.Khatun etal 2014].

\subsection{Pharmaceutical formulations:}

Azarga eye drops, manufactured by ALCON-COUVREUR (Belgium). Batch number 180416, labeled to contain $10 \mathrm{mg} / \mathrm{mL}$ BRZ and $5 \mathrm{mg} / \mathrm{mL}$ TML, purchased from local market.

\subsection{Stock standard solution}

\section{1- Stock standard solution of BRZ $(0.6 \mathrm{mg} / \mathrm{mL})$}

An accurately weighed $6 \mathrm{mg}$ of BRZ was dissolved in $10 \mathrm{~mL}$ methanol in 10$\mathrm{mL}$ volumetric flask and completed to the volume with the same solvent.

\section{2- Stock standard solution of TML $(0.6 \mathrm{mg} / \mathrm{mL})$}

An accurately weighed $6 \mathrm{mg}$ of TML was dissolved in $10 \mathrm{~mL}$ methanol in 10$\mathrm{mL}$ volumetric flask and completed to the volume with the same solvent.

Aliquots of the prepared stock solutions were further diluted with methanol to a final volume of $10 \mathrm{~mL}$. The diluted solutions were used as the working solutions for BRZ and TML.

\subsection{Construction of calibration curves:}

Standard solutions of both BRZ and TML in the range of $(6-36 \mu \mathrm{g} / \mathrm{mL})$ and $(6-$ $42 \mu \mathrm{g} / \mathrm{mL}$ ), respectively, were separately prepared by appropriate dilutions of their respective stock standard solutions in methanol. The absorption spectra of the resulting solutions were measured in the range of 200-400 nm using methanol as blank and stored in the computer.

\subsubsection{Ratio difference spectrophotometric method (RDSM)}

The stored spectra of BRZ were divided by the spectrum of $12 \mu \mathrm{g} / \mathrm{mL}$ of TML to obtain ratio spectra, as well as the spectra of TML were divided by the spectrum of $12 \mu \mathrm{g} / \mathrm{mL}$ of BRZ. A two calibration curves were constructed relating the difference between the amplitudes of ratio spectra of BRZ and TML at (251 and $265 \mathrm{~nm})$ and (285 and $306 \mathrm{~nm}$ ), respectively, versus the corresponding concentrations of BRZ and TML, respectively, and the regression equations were computed.

\subsubsection{Mean centering of ratio spectra method (MCR)}

The stored spectra of BRZ were divided by the spectrum of $12 \mu \mathrm{g} / \mathrm{mL}$ of TML to obtain ratio spectra, as well as the spectra of TML were divided by the spectrum of 
$12 \mu \mathrm{g} / \mathrm{mL}$ of BRZ, the obtained ratio spectra of both mentioned drugs were mean centered. Two calibration curves were constructed relating the mean center values of BRZ at $252 \mathrm{~nm}$ and TML at $304 \mathrm{~nm}$, respectively, versus the corresponding concentrations of BRZ and TML, respectively, and the regression equations were computed.

\subsubsection{Area under the curve method (AUC)}

The AUC of BRZ was measured between (260 -265) nm for BRZ and between (282 -288) $\mathrm{nm}$ for TML. The calibration curve of the mentioned drugs was plotted relating area under the curve versus the corresponding concentrations of BRZ and TML, and then the regression equations and the absorptivity constants were computed.

\subsubsection{Bivariate method (BVM)}

The absorption spectra of the prepared solutions were measured at 265, 270, 275, 280 and $285 \mathrm{~nm}$. Four calibration curves; 2 calibrations for each component at 2 wavelengths selected using method of Kaiser at 265 and $285 \mathrm{~nm}$, were constructed against the corresponding concentrations of BRZ and TML, and the corresponding regression equations were computed.

\subsection{Analysis of laboratory prepared mixtures different ratios of BRZ and TML using the proposed methods}

Six laboratory prepared mixtures containing different ratios of BRZ and TML were analyzed using the suggested methods. The concentrations of BRZ and TML were calculated from their corresponding regression equations.

\subsection{Assay of pharmaceutical formulations}

AZARGA eye drops bottle each one $\mathrm{mL}$ is claimed to contain $10 \mathrm{mg}$ of brinzolamide and $5 \mathrm{mg}$ of timolol maleate equivalent to $5 \mathrm{mg}$ timolol mixed with reported excipients like $0.1 \%$ benzalkonium chloride, $0.1 \mathrm{mg}$ mannitol, and $0.1 \mathrm{mg}$ sodium chloride.

One $\mathrm{ml}$ of Azarga eye drop was transferred to $10 \mathrm{ml}$ volumetric flask, $8 \mathrm{~mL}$ methanol were added and sonicated for 10 minutes then filtered. The volume was completed to the mark with methanol to get $1000 \mu \mathrm{g} / \mathrm{mL}$ BRZ and $500 \mu \mathrm{g} / \mathrm{mL}$ TML. From the above prepared solution, further dilutions were performed in the obtained linearity ranges using methanol for the adopted spectrophotometric methods. The procedure of each of the suggested methods was applied to determine the concentration of the cited drugs in the prepared dosage form solution. The determination was performed in triplicate for each concentration. Concentrations of BRZ and TML in the prepared samples were calculated from their corresponding regression equations.

\section{Results and discussion}

The main target of this paper is to develop four sensitive, simple and precise spectrophotometric methods for the simultaneous determination of (BRZ) and (TML) in bulk drugs and in their pharmaceutical formulation. Since there are few analytical methods available for the simultaneous estimation of Brinzolamide and Timolol in their combined pharmaceutical formulation. 
The suggested methods; Ratio difference, Mean centering of ratio spectra, Area under the curve and Bivariate spectrophotometric methods, were applied to resolve the spectral overlap of BRZ and TML in their binary mixture without prior separation steps.

\subsection{Method development and optimization}

\subsubsection{Ratio difference spectrophotometric method (RDSM)}

Ratio difference method is simple and accurate method that has the ability for solving severely overlap spectra without prior separation at the same time it does not require any sophisticated apparatus or computer programs. It can determine the unknown concentration of a component of interest present in a mixture containing both the component of interest and an interfering component [H.M.Lotfy et al. 2014].

The zero order absorption spectra of the laboratory-prepared mixtures of BRZ and TML are divided by a concentration of $12 \mu \mathrm{g} / \mathrm{mL}$ of BRZ and $12 \mu \mathrm{g} / \mathrm{mL}$ of TML as a divisor for the determination of BRZ and TML, respectively separately to get the ratio spectra shown in( Fig. 2and 3). Different pairs of wavelengths were selected to choose the optimum wavelengths at which measurements were done, the amplitudes at $251 \mathrm{~nm}$ and $265 \mathrm{~nm}$ were selected for determination of BRZ and 285 and $306 \mathrm{~nm}$ for determination of TML which provide the best selectivity. The concentration of BRZ and TML were obtained using their corresponding regression equations obtained by plotting the difference in the amplitudes at $251-265 \mathrm{~nm}$ and $285-306 \mathrm{~nm}$ respectively, of the ratio spectra against their corresponding concentrations:

$$
\begin{array}{lr}
\operatorname{RDSM}_{\mathrm{BRZ}}=0.4020 \mathrm{C}-0.4088 & \mathrm{r}=0.9993 \\
\operatorname{RDSM}_{\mathrm{TML}}=0.2827 \mathrm{C}-0.0934 & \mathrm{r}=0.9999
\end{array}
$$

Where $\mathrm{C}$ is the concentrations of cited drugs $\mu \mathrm{g} / \mathrm{mL}$, RDSM is the difference in peak amplitudes of the ratio spectrum curves and $\mathrm{r}$ is the correlation coefficient.

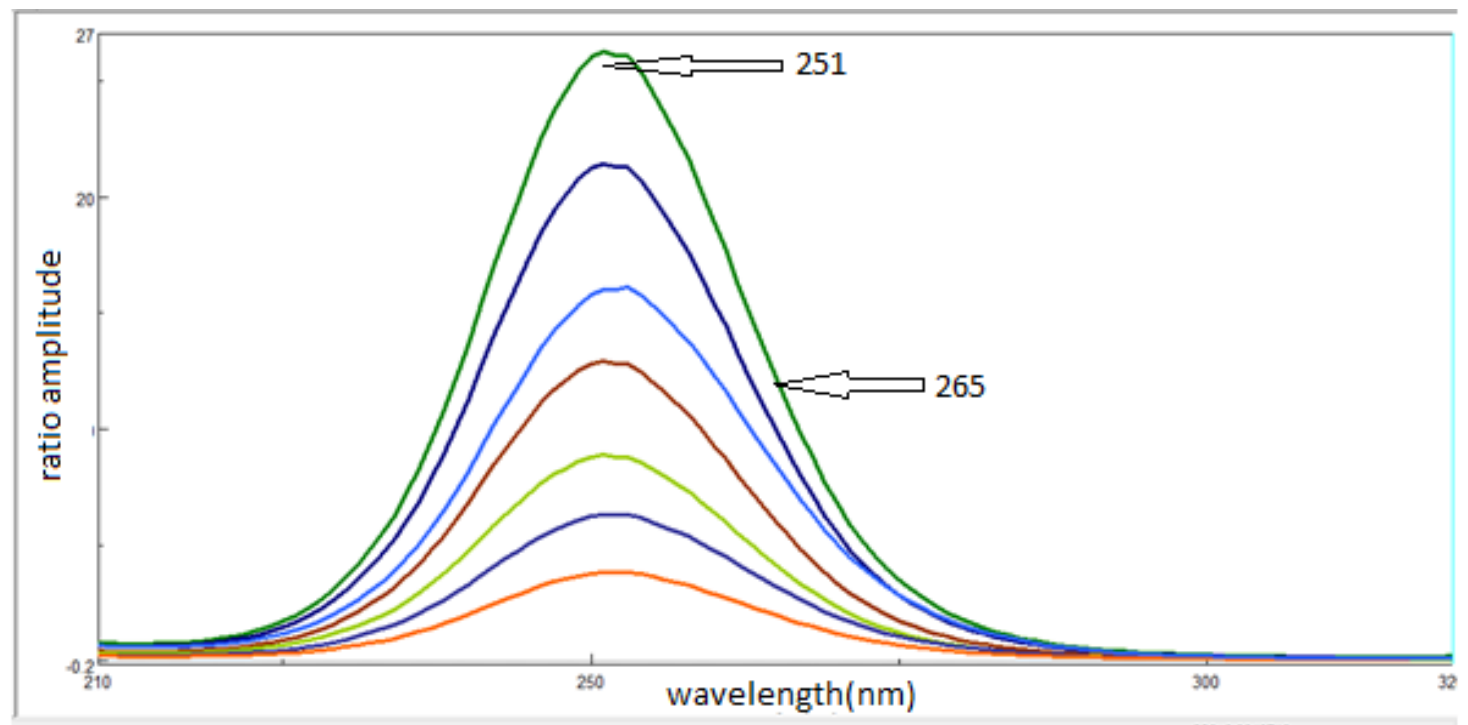

Fig. (2): Ratio spectra of $(6-36 \mu \mathrm{g} / \mathrm{mL})$ brinzolamide using the spectrum of $12 \mu \mathrm{g} / \mathrm{mL}$ timolol as divisor. 


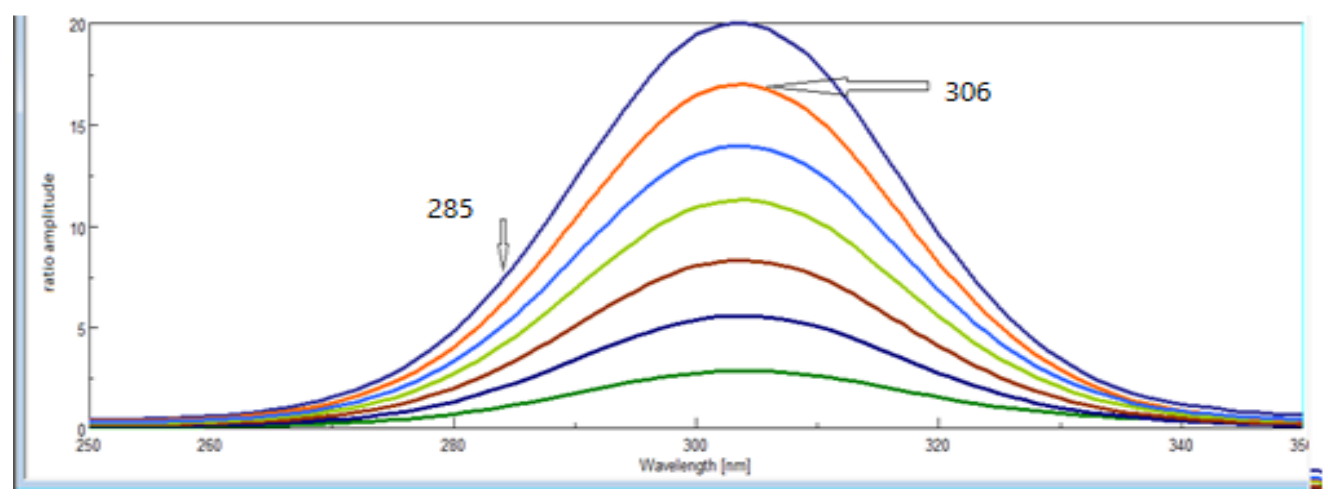

Fig.(3): Ratio spectra of timolol $(6-42 \mu \mathrm{g} / \mathrm{mL})$ using the spectrum of $12 \mu \mathrm{g} / \mathrm{mL}$ brinzolamide as divisor.

\subsubsection{Mean centering method (MCR)}

This method depends on the mean centering of ratio spectra. It eliminates the derivative step so the signal-to-noise ratio is enhanced [A.Afkham et al. 2004 A.Afkham et al. 2005 - M.Bahram et al. 2007]. Mean centering method was applied to determine concentration of $\mathrm{BRZ}$ in presence of TML and vice versa. For determination of BRZ, the absorption spectra of BRZ were divided by the absorption spectrum of $12 \mu \mathrm{g} / \mathrm{mL}$ of $\mathrm{TML}$ as a divisor and for determination of TML, the absorption spectra of TML were divided by the absorption of $12 \mu \mathrm{g} / \mathrm{mL}$ of BRZ as a divisor. The obtained ratio spectra were mean centered and the concentrations of BRZ and TML were determined by measuring the amplitude at $252 \mathrm{~nm}$ and at $304 \mathrm{~nm}$, respectively (Fig.4and5). The linear regression equation is found to be:

$$
\begin{array}{cc}
\operatorname{MCN}_{\text {BRZ }}=0.6292 \mathrm{C}-0.6595 & \mathrm{r}=0.9995 \\
\mathrm{MCN}_{\mathrm{TML}}=0.3829 \mathrm{C}+0.2796 & \mathrm{r}=0.9997
\end{array}
$$

Where $\mathrm{C}$ is the concentrations of the cited drugs, $\mathrm{MCN}$ is the peak amplitude of the mean centered ratio spectrum curve and $\mathrm{r}$ is the correlation coefficient.

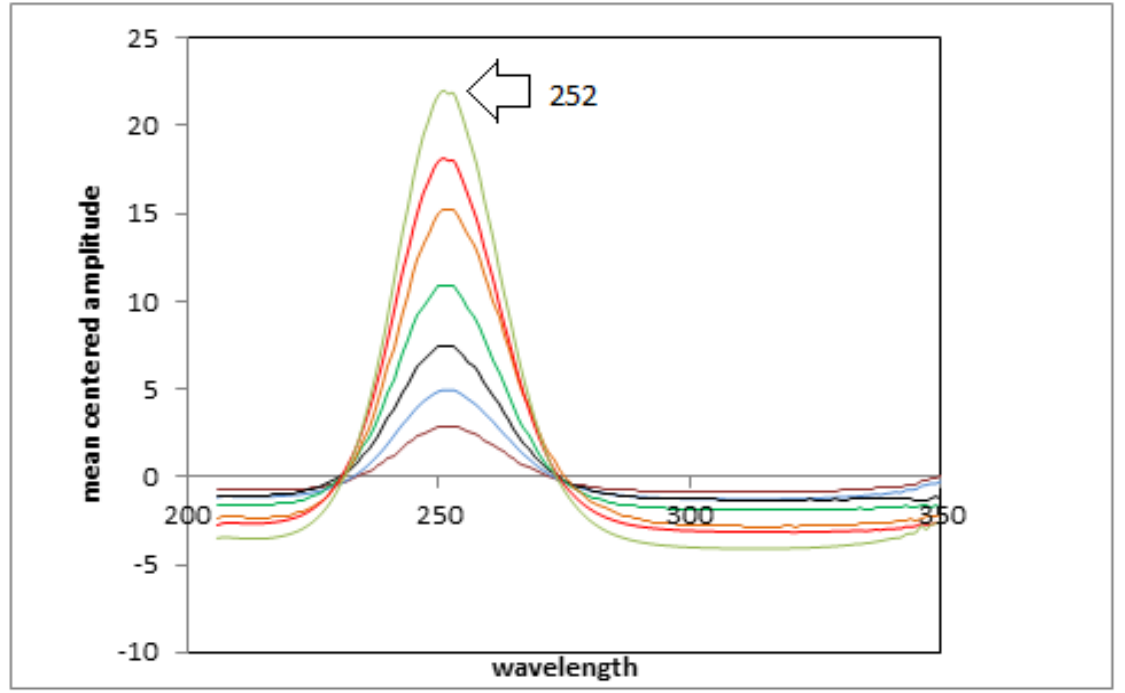

Fig.(4).Mean centered ratio spectra of brinzolamide $(6-30 \mu \mathrm{g} / \mathrm{mL})$ using 12 $\mu \mathrm{g} / \mathrm{mL}$ of timolol as a divisor. 


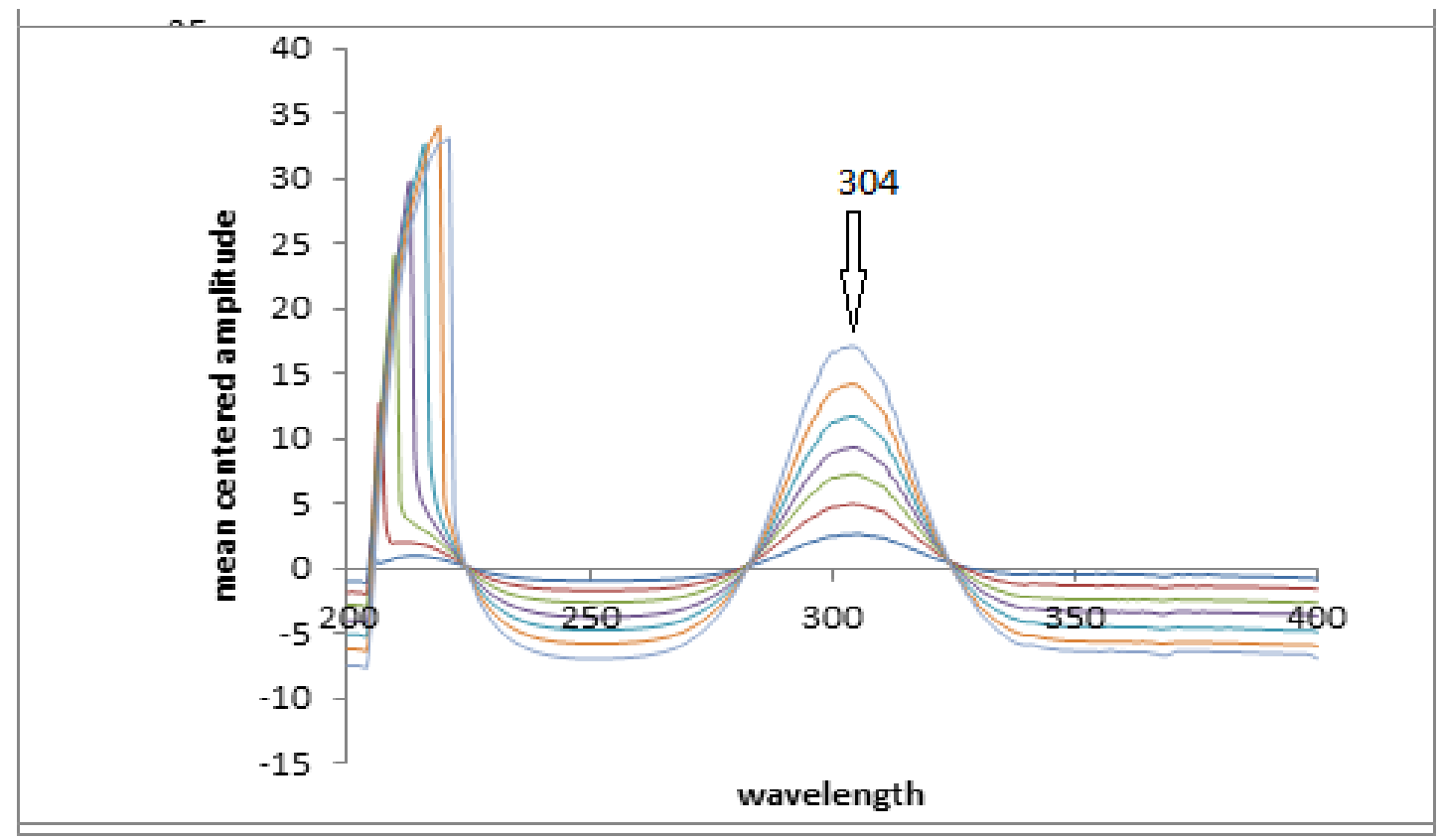

Fig.(5). Mean centered ratio spectra of timolol $(6-36 \mu \mathrm{g} / \mathrm{mL})$ using 12 $\mu \mathrm{g} / \mathrm{mL}$ of brinzolamide as a divisor.

\subsubsection{Area under the curve method (AUC)}

AUC [M.M.Abdelrahman et al. 2013] is an accurate, rapid and selective method for the simultaneous determination of components having overlain spectra in binary mixtures by calculating the areas under the spectra in relation to their concentrations. Careful choice of the wavelength ranges at which calculations were done was of great importance, so different pairs of wavelength ranges were selected to choose the optimum wavelength range.

Area under the curves obtained from the scanned spectra over the ranges of wavelengths (260 - 265) and (282 - 388) nm (Fig.6 and 7) were recorded and then the corresponding regression equations were obtained for both BRZ and TML.

-For BRZ:

$$
\begin{array}{lr}
Y_{(260-265)}=0.1499 x-0.0161 & (r=0.9990) . \\
Y_{(282-388)}=0.0323 x+0.0306 & (r=0.9988) . \\
\text {-For TML: } & (r=0.9991) . \\
Y_{(260-265)}=0.0359 x-0.0689 & (r=0.9998) . \\
Y_{(282-388)}=0.1297 x-0.0689 &
\end{array}
$$

Where $y$ is the area under curve over the ranges (260-265) and (282-388) respectively, $x$ is the concentration in $\mu \mathrm{g} / \mathrm{mL}$ and $\boldsymbol{r}$ is the correlation coefficient

Areas under the curve and the absorptivity values at the selected wavelength ranges are used for calculating the concentration of BRZ in presence of TML and vice versa using the following equations: 


$$
\begin{aligned}
& C^{X}=\frac{\left(\begin{array}{lll}
a_{\lambda 1-\lambda 2} & A U C_{\lambda 3-\lambda 4}
\end{array}\right)-\left(\begin{array}{ll}
a^{Y}{ }_{\lambda 3-\lambda 4} & A U C_{\lambda 1-\lambda 2}
\end{array}\right)}{\left(\begin{array}{lll}
a_{\lambda 1-\lambda 2}^{Y} & \left.a^{X} \lambda 3-\lambda 4\right)-\left(a_{\lambda 3-\lambda 4}^{Y}\right. & a^{X} \lambda 1-\lambda 2
\end{array}\right)}
\end{aligned}
$$

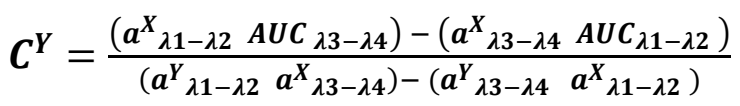

- Where $\mathrm{C}^{\mathrm{X}}, \mathrm{C}^{\mathrm{Y}}$ are the concentrations of the cited drugs.

- $a_{\lambda 1-\lambda 2}^{X}, a_{\lambda 3-\lambda 4}^{X}$ are the absorptivity of drug $X$ at $(\lambda 1-\lambda 2) \mathrm{nm}$ and at $(\lambda 3-$ $\lambda 4) \mathrm{nm}$

, Respectively.

- $a_{\lambda 1-\lambda 2}^{Y}, a_{\lambda 3-\lambda 4}^{Y}$ are the absorptivity of drug $Y$ at $(\lambda 1-$ $\lambda 2) n m$ and at $(\lambda 3-\lambda 4) n m$, respectively.

- $\quad A U C_{\lambda 1-\lambda 2} A U C_{\lambda 3-\lambda 4}$ are the area under the curves at $(\lambda 1-\lambda 2) \mathrm{nm}$ and at $(\lambda 3-\lambda 4) \mathrm{nm}$, respectively .

The calibration graphs that relate the measured areas under the curve to the concentration of each component in $\mu \mathrm{g} / \mathrm{mL}$ were constructed.

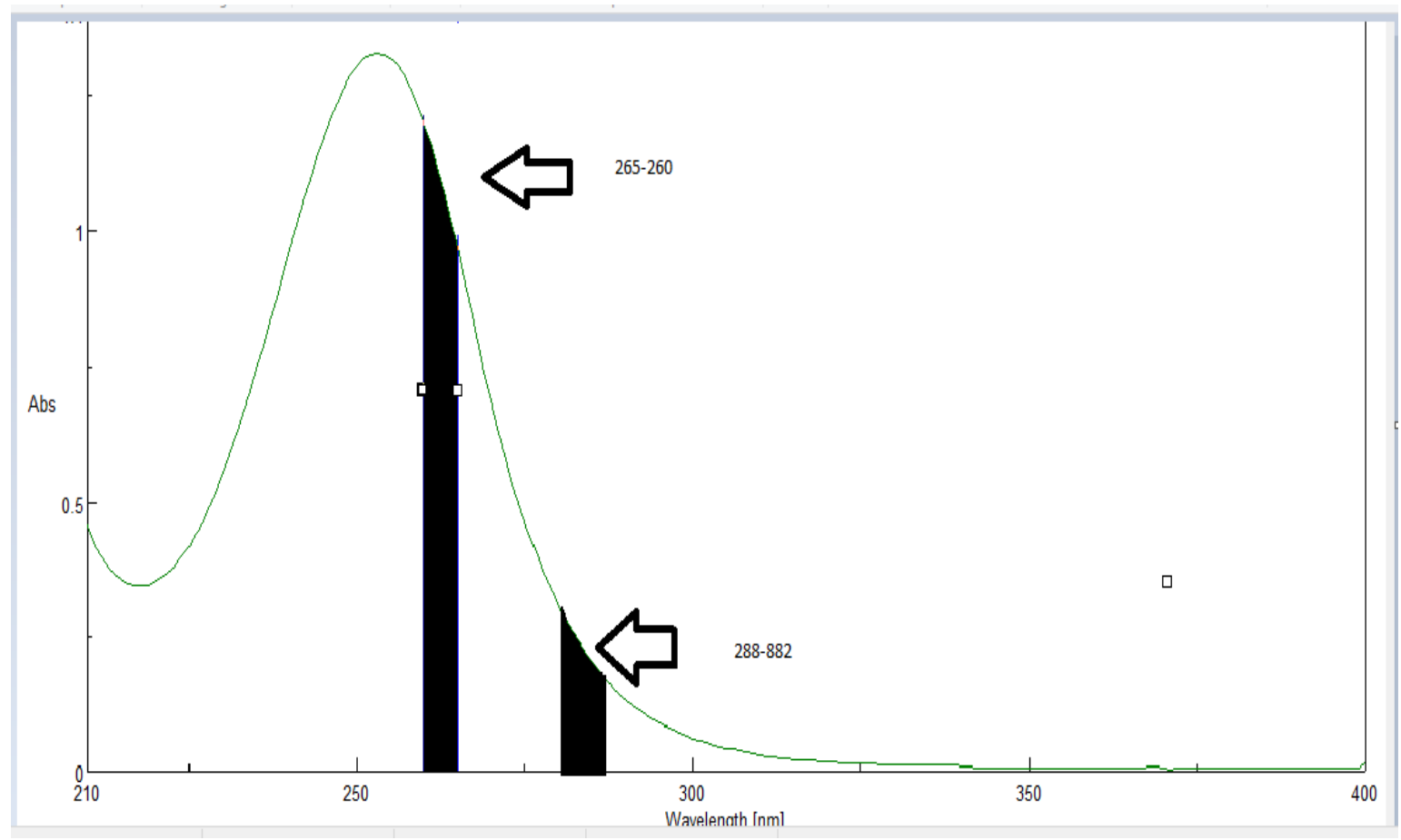

Fig. (6): Zero order absorption spectrum of brinzolamide $(36 \mu \mathrm{g} / \mathrm{ml})$ showing area under the curve over the ranges (260-265) and (282-288) $\mathrm{nm}$. 


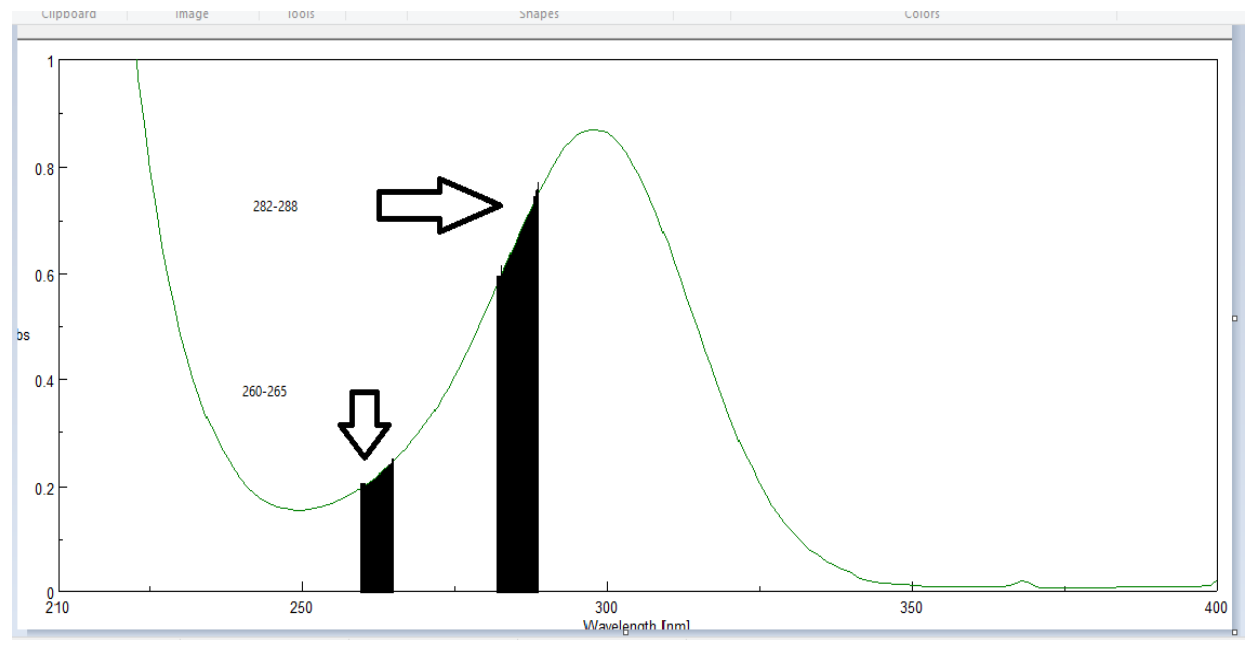

Fig. (7): Zero order absorption spectrum of timolol $(36 \mu \mathrm{g} / \mathrm{ml})$ showing area under the curve over the ranges (260-265) and (282-288) $\mathrm{nm}$.

\subsubsection{Bivariate method (BVM)}

This method depends on a simple mathematical algorithm, in which the data ara used from four regression equations, two calibrations for each component at two selected wavelengths using Kaiser method [D.Massart et al. 1988]. The absorbance was measured at the selected wavelengths and the corresponding regression equations were calculated for both BRZ and TML. The calculated slope and intercept values were used for obtaining concentration of each compound using the following equation:

$$
A_{A B 1}-e_{A B 1}-m_{B 1} C_{B}
$$

$\mathrm{C}_{\mathrm{A}}=$

$$
\mathrm{m}_{\mathrm{A} 1}
$$

$C_{B}=\frac{m_{A 2}\left(A_{A B 1}-e_{A B 1}\right)+m_{A 1}\left(e_{A B 2}-A_{A B 2}\right)}{A}$

$$
m_{\mathrm{A} 2} m_{\mathrm{B} 1}-m_{\mathrm{A} 1} m_{\mathrm{B} 2}
$$

- Where $\mathrm{C}_{\mathrm{A}}, \mathrm{C}_{\mathrm{B}}$ are the concentrations of the analytes.

$-\mathrm{A}_{\mathrm{AB} 1}, \mathrm{~A}_{\mathrm{AB} 2}$ are the absorbances of the drug mixture at the two selected wavelengths (1 and 2), respectively.

$-\mathrm{e}_{\mathrm{AB} 1}, \mathrm{e}_{\mathrm{AB} 2}$ are the sum of the intercepts of the linear calibration at two wavelengths $\left(\mathrm{e}_{\mathrm{AB} 1}=\mathrm{e}_{\mathrm{A} 1+}+\mathrm{e}_{\mathrm{B} 1}\right)$.

$-\mathrm{m}_{\mathrm{A} 1,2}, \mathrm{~m}_{\mathrm{B} 1,2}$ are the slopes of the linear regression.

For BRZ and TML mixture, five wavelengths (265, 270, 275, 280, $285 \mathrm{~nm})$ were chosen and Kaiser Method is used to select two wavelength at which four regression equations, two calibrations for each component were obtained. The selected wavelengths are $265.0 \mathrm{~nm}$ and $285.0 \mathrm{~nm}$. At these selected wavelengths, the onecomponent calibration curves were obtained in the range of $(6-36 \mu \mathrm{g} / \mathrm{mL})$ for BRZ and $(6-42 \mu \mathrm{g} / \mathrm{mL})$ for TML. The linear regression equations were found to be: 


$$
\begin{array}{lll}
\mathrm{A}_{265}=0.02162 \mathrm{C}-0.0025 & \mathrm{r}=0.9998 & \text { at } 265 \mathrm{~nm} \text { for BRZ } \\
\mathrm{A}_{285}=0.0049 \mathrm{C}-0.0119 & \mathrm{r}=0.9993 & \text { at } 285 \mathrm{~nm} \text { for BRZ } \\
\mathrm{A}_{265}=0.0067 \mathrm{C}-0.0020 & \mathrm{r}=0.9994 & \text { at } 265 \mathrm{~nm} \text { for TML } \\
\mathrm{A}_{285}=0.0182 \mathrm{C}-0.0012 & \mathrm{r}=0.9998 & \text { at } 285 \mathrm{~nm} \text { for TML }
\end{array}
$$

Where $\mathrm{A}$ is the absorbance value at $265 \mathrm{~nm}$ and $285 \mathrm{~nm}, \mathrm{C}$ is the concentration in $\mu \mathrm{g} / \mathrm{mL}$ and $\mathrm{r}$ is the correlation coefficient.

\subsection{Method validation} 2005] .

The applied methods had been validated according to ICH guidelines [ICH

\subsubsection{Linearity \& Range:}

The linearity of the methods was evaluated by analyzing six concentrations of BRZ and seven concentrations of TM ranging from $6-36 \mu \mathrm{g} / \mathrm{ml}$ and $6-42 \mu \mathrm{g} / \mathrm{mL}$, respectively. The linear regression parameters were listed in Table1.

\subsubsection{Accuracy}

The accuracy of suggested method was checked by analyzing five different concentrations of each drug in triplicate within the linearity range where percentage recoveries suggested satisfactory results of the accuracy of the performed methods as shown in Table 1. The validity of the method was checked by applying the standard addition technique, where satisfactory results are obtained Table 2.

\subsubsection{Selectivity}

The selectivity of the methods was assessed by the analysis of laboratory prepared mixtures of BRZ and TM in different ratios within the linearity range where good results were obtained as shown in Table 3.

\subsubsection{Precision}

Precision of the adopted methods was evaluated by performing intra-day and inter-day precision studies. The intra- and inter-day precision were assessed using three different concentrations of each of BRZ and TML in triplicate on the same day and on three successive days using the proposed methods, respectively. The relative standard deviations were obtained Table 1.

\subsubsection{Limit of detection (LOD) and Limit of quantification (LOQ):}

The LOD and LOQ of the suggested methods were checked and calculated from the standard deviation $(\sigma)$ of the response and the slope of the calibration curve (S) according to the equations: $\mathrm{LOD}=3.3 \times \sigma / \mathrm{S}, \mathrm{LOQ}=10 \mathrm{\times} \sigma / \mathrm{S}$ and the results were obtained as shown in Table1.

\subsection{Application of the methods in assay of eye drops}

The suggested methods are applicable for the analysis of BRZ and TM in their combined pharmaceutical formulation Azarga eye drops with no interference from the excipients; the results are shown in Table 2. 


\subsection{Statistical analysis}

Statistical comparison between the results obtained by the suggested methods and those obtained by the reported HPLC method [R.Khatun etal 2014] showed no significant differences as shown in Table 4.

Table1. Regression parameters and results of determination of pure samples of BRZ and TML by the proposed methods.

\begin{tabular}{|c|c|c|c|c|c|c|c|c|c|c|c|c|}
\hline \multirow{3}{*}{$\begin{array}{c}\text { Parameter } \\
\lambda(\mathrm{nm})\end{array}$} & \multicolumn{2}{|c|}{ RDSM } & \multicolumn{2}{|c|}{ MC } & \multicolumn{4}{|c|}{ AUC } & \multicolumn{4}{|c|}{ Bivariate } \\
\hline & \multirow{2}{*}{$\begin{array}{c}\text { BRZ } \\
\text { P251- } \\
265\end{array}$} & \multirow{2}{*}{$\begin{array}{c}\text { TML } \\
\text { P285- } \\
306 \\
\end{array}$} & \multirow{2}{*}{$\begin{array}{r}\text { BRZ } \\
252\end{array}$} & \multirow{2}{*}{\begin{tabular}{|c|} 
TML \\
304
\end{tabular}} & \multicolumn{2}{|c|}{ BRZ } & \multicolumn{2}{|c|}{ TML } & \multicolumn{2}{|c|}{ BRZ } & \multicolumn{2}{|c|}{ TML } \\
\hline & & & & & $\begin{array}{l}260- \\
265\end{array}$ & $\begin{array}{l}282- \\
288\end{array}$ & $\begin{array}{l}260- \\
265\end{array}$ & $\begin{array}{l}282- \\
288\end{array}$ & 265 & 285 & 265 & 285 \\
\hline $\begin{array}{l}\text { Range } \\
(\mu \mathrm{g} / \mathrm{ml})\end{array}$ & 6-36 & $6-42$ & $6-36$ & $6-36$ & $6-36$ & $6-36$ & $6-36$ & 6-36 & 6-30 & 6-30 & 6-36 & $\overline{6-36}$ \\
\hline Slope & 0.4020 & 0.2827 & $\begin{array}{c}0.629 \\
2\end{array}$ & $\begin{array}{c}0.382 \\
9\end{array}$ & $\begin{array}{c}0.149 \\
9\end{array}$ & $\begin{array}{c}0.032 \\
3\end{array}$ & $\begin{array}{c}0.035 \\
9\end{array}$ & $\begin{array}{c}0.129 \\
7\end{array}$ & $\begin{array}{c}0.026 \\
161\end{array}$ & $\begin{array}{c}0.004 \\
9\end{array}$ & $\begin{array}{c}0.006 \\
7\end{array}$ & $\begin{array}{c}0.018 \\
2\end{array}$ \\
\hline intercept & -0.4088 & -0.0934 & 0.659 & $\begin{array}{c}0.279 \\
6\end{array}$ & $\begin{array}{c}-\overline{0} \\
0.016\end{array}$ & $\begin{array}{c}0.030 \\
6\end{array}$ & $\begin{array}{c}0.068 \\
9\end{array}$ & $\begin{array}{c}0.068 \\
9\end{array}$ & $\begin{array}{c}0.002 \\
5\end{array}$ & $\begin{array}{c}0.011 \\
9\end{array}$ & $\begin{array}{c}0.002 \\
0\end{array}$ & $\begin{array}{c}- \\
0.001\end{array}$ \\
\hline $\begin{array}{l}\text { Correlation } \\
\text { Coefficient } \\
(\mathrm{r})\end{array}$ & 0.9993 & 0.9999 & $\begin{array}{c}0.999 \\
5\end{array}$ & $\begin{array}{c}0.999 \\
7\end{array}$ & $\begin{array}{c}0.999 \\
0\end{array}$ & $\begin{array}{c}0.998 \\
8\end{array}$ & $\begin{array}{c}0.999 \\
1\end{array}$ & $\begin{array}{c}0.999 \\
8\end{array}$ & $\begin{array}{c}0.999 \\
8\end{array}$ & $\begin{array}{c}0.999 \\
3\end{array}$ & $\begin{array}{c}0.999 \\
4\end{array}$ & $\begin{array}{c}0.990 \\
8\end{array}$ \\
\hline $\begin{array}{c}\text { LOD } \\
(\mu \mathrm{g} / \mathrm{ml})\end{array}$ & 1.41 & 0.53 & 1.17 & 0.96 & 1.72 & 1.86 & 1.64 & 0.78 & 0.78 & 1.43 & 1.30 & 0.71 \\
\hline $\begin{array}{c}\text { LOQ } \\
(\mu \mathrm{g} / \mathrm{ml})\end{array}$ & 4.27 & 1.59 & 3.53 & 2.92 & 5.22 & 5.63 & 4.97 & 2.36 & 2.37 & 4.36 & 3.94 & 2.14 \\
\hline $\begin{array}{c}\text { Accuracy } \\
(\text { mean } \pm \text { SD) }\end{array}$ & $\begin{array}{c}100.07 \\
\pm\end{array}$ & $\begin{array}{c}99.86 \\
\pm\end{array}$ & $\begin{array}{c}99.90 \\
\pm\end{array}$ & $\begin{array}{c}99.69 \\
\pm\end{array}$ & 99 & & & & 10 & & 10 & \\
\hline $\mathrm{RSD} \%^{\mathrm{a}}$ & 0.886 & 0.492 & 0.795 & 0.459 & 0.3 & & & & & & & \\
\hline $\mathrm{RSD}^{\mathrm{b}}$ & 1.101 & 0.630 & 0.944 & 1.625 & 0.8 & & & & & & & \\
\hline
\end{tabular}

RSD $\%^{\mathrm{a}}$ : the intra-day relative standard deviation of 12,24 and $36 \mu \mathrm{g} / \mathrm{mL}$ of BRZ and TML by the proposed methods.

RSD $\%^{\mathrm{b}}:$ \& inter-day respectively relative standard deviation of 12,24 and $36 \mu \mathrm{g} / \mathrm{mL}$ of BRZ and TML by the proposed methods. 
Table2. Determination of BRZ and TML in Azarga eye drop by the proposed methods and application of standard addition technique.

\begin{tabular}{|c|c|c|c|c|}
\hline Sample & \multicolumn{4}{|c|}{ BRZ } \\
\hline Method & RDSM & $\mathrm{MC}$ & AUC & Bivariate \\
\hline $\begin{array}{c}\text { Azarga } \\
\mathrm{R}^{*} \% \pm \mathrm{SD}\end{array}$ & $\begin{array}{c}101.28 \\
\pm \\
0.477\end{array}$ & $\begin{array}{c}102.10 \\
\pm \\
0.596\end{array}$ & $\begin{array}{c}101.05 \\
\pm \\
0.530\end{array}$ & $\begin{array}{c}100.83 \\
\pm \\
1.553\end{array}$ \\
\hline $\begin{array}{c}\text { Standard Addition } \\
\mathrm{R}^{* *} \% \pm \mathrm{SD}\end{array}$ & $\begin{array}{c}100.50 \\
\pm \\
0.670 \\
\end{array}$ & $\begin{array}{c}99.65 \\
\pm \\
1.628 \\
\end{array}$ & $\begin{array}{c}100.38 \\
\pm \\
0.405\end{array}$ & $\begin{array}{c}100.42 \\
\pm \\
1.457 \\
\end{array}$ \\
\hline Sample & \multicolumn{4}{|c|}{ TML } \\
\hline Method & RDSM & $\mathrm{MC}$ & AUC & Bivariate \\
\hline $\begin{array}{c}\text { Azarga } \\
\mathrm{R}^{*} \% \pm \mathrm{SD}\end{array}$ & $\begin{array}{c}101.26 \\
\pm \\
0.628\end{array}$ & $\begin{array}{c}100.96 \\
\pm \\
1.583\end{array}$ & $\begin{array}{c}101.13 \\
\pm \\
0.983\end{array}$ & $\begin{array}{c}100.63 \\
\pm \\
1.748\end{array}$ \\
\hline $\begin{array}{c}\text { Standard Addition } \\
\mathrm{R}^{* *} \% \pm \mathrm{SD}\end{array}$ & $\begin{array}{c}101.12 \\
\pm \\
0.610\end{array}$ & $\begin{array}{c}100.71 \\
\pm \\
0.669 \\
\end{array}$ & $\begin{array}{c}99.84 \\
\pm \\
1.326 \\
\end{array}$ & $\begin{array}{c}99.50 \\
\pm \\
0.785 \\
\end{array}$ \\
\hline
\end{tabular}

*Average of six determinations.

** Average of nine determinations over three concentration levels.

Table3. Determination of the studied drugs in the laboratory prepared mixtures.

\begin{tabular}{|c|c|c|c|c|c|c|c|c|c|}
\hline \multicolumn{2}{|c|}{$\begin{array}{c}\text { Concentration } \\
{[\mu \mathrm{g} / \mathrm{mL}]}\end{array}$} & \multicolumn{2}{c|}{ RDSM } & \multicolumn{2}{c|}{ MC } & \multicolumn{2}{c|}{ AUC } & \multicolumn{2}{c|}{ Bivariate } \\
\cline { 2 - 10 } & \multicolumn{2}{c|}{ Recovery \% } & \multicolumn{2}{c|}{ Recovery \% } & \multicolumn{2}{c|}{ Recovery \% } & \multicolumn{2}{c|}{ Recovery \% } \\
\hline BRZ & TML & BRZ & TML & BRZ & TML & BRZ & TML & BRZ & TML \\
\hline 30 & 12 & 100.02 & 99.8 & 99.40 & 99.73 & 100.75 & 99.05 & 99.55 & 100.31 \\
\hline 24 & 18 & 102.06 & 100.13 & 100.16 & 97.90 & 101.20 & 98.66 & 99.87 & 99.81 \\
\hline 24 & 12 & 99.89 & 100.13 & 100.24 & 99.45 & 99.78 & 101.19 & 100.08 & 100.10 \\
\hline 24 & 6 & 99.96 & 96.57 & 99.89 & 98.38 & 99.98 & 99.95 & 100.04 & 100.20 \\
\hline 12 & 12 & 102.06 & 100.01 & 98.91 & 99.89 & 99.65 & 97.65 & 100.10 & 99.88 \\
\hline 18 & 12 & 99.71 & 99.9 & 101.62 & 99.33 & 99.82 & 102.00 & 99.43 & 101.03 \\
\hline \multicolumn{2}{|c|}{ Mean } & 100.62 & 99.42 & 100.04 & 99.11 & 100.20 & 99.75 & 99.84 & 100.22 \\
\hline \multicolumn{2}{|c|}{ SD } & 1.123 & 1.404 & 0.923 & 0.794 & 0.628 & 1.629 & 0.289 & 0.439 \\
\hline \multicolumn{2}{|c|}{ RSD } & 1.116 & 1.412 & 0.923 & 0.801 & 0.627 & 1.633 & 0.290 & 0.438 \\
\hline
\end{tabular}


Table4. Statistical analysis of the proposed methods and the reported method of BRZ and TML in their pharmaceutical dosage form.

\begin{tabular}{|c|c|c|c|c|c|}
\hline \multirow{2}{*}{ Parameter } & \multicolumn{5}{|c|}{ BRZ } \\
\hline & RDSM & MCR & AUC & Bivariate & Reported method $[1]^{\mathrm{c}}$ \\
\hline Mean $\%^{\mathrm{a}}$ & 101.28 & 102.10 & 101.05 & 100.83 & 101.95 \\
\hline $\mathrm{SD}$ & 0.477 & 0.596 & 0.530 & 1.553 & 0.863 \\
\hline $\mathrm{N}$ & 6 & 6 & 6 & 6 & 6 \\
\hline Variance & 0.228 & 0.355 & 0.281 & 2.412 & 0.745 \\
\hline $\begin{array}{l}\text { t-test } \\
(2.23)^{b}\end{array}$ & 1.66 & 0.35 & 2.18 & 1.54 & \\
\hline \multirow[t]{3}{*}{$\begin{array}{c}\mathrm{F} \\
(5.05)^{\mathrm{b}}\end{array}$} & 3.27 & 2.10 & 2.65 & 3.24 & \\
\hline & \multicolumn{5}{|c|}{ TML } \\
\hline & RDSM & MCR & AUC & Bivariate & Reported method[1] $]^{\mathrm{c}}$ \\
\hline Mean $\%^{\mathrm{a}}$ & 101.26 & 100.96 & 101.13 & 100.63 & 101.98 \\
\hline $\mathrm{SD}$ & 0.628 & 1.583 & 0.983 & 1.748 & 0.832 \\
\hline $\mathrm{N}$ & 6 & 6 & 6 & 6 & 6 \\
\hline Variance & 0.394 & 2.506 & 0.966 & 3.055 & 0.692 \\
\hline $\begin{array}{l}\text { t-test } \\
(2.23)^{b}\end{array}$ & 1.69 & 1.40 & 1.62 & 1.71 & \\
\hline $\begin{array}{c}\mathrm{F} \\
(5.05)^{\mathrm{b}}\end{array}$ & 1.76 & 3.62 & 1.40 & 4.41 & \\
\hline
\end{tabular}

\section{Conclusion}

From the previous discussion, it could be concluded that the applied methods were simple with minimum manipulation steps, accurate, don't need any sophisticated apparatus and could be easily applied in quality control laboratories.

The developed methods were validated as per ICH guidelines and were found to be precise as revealed from \% RSD less than 2, for simultaneous estimation of BRZ and TML in mixture over the applied range. Finally the suggested method could be successfully applied for the routine analysis of BRZ and TML in their pure bulk powders and in their combined ophthalmic preparation without prior separation procedure steps. 


\section{REFERENCES}

A. Afkhami, M. Bahram, (2004) Mean centering of ratio kinetic profiles as a novel spectrophotometric method for the simultaneous kinetic analysis of binary mixtures, Analytica chimica acta, 526 211-218.

A. Afkhami, M. Bahram, (2005) Mean centering of ratio spectra as a new spectrophotometric method for the analysis of binary and ternary mixtures, Talanta, 66 712-720.

D. Massart, B. Vandeginste, S. Deming, Y. Michotte, L. Kaufman, (1988) Chemometrics: a textbook Elsevier Amsterdam Google Scholar,

H.M. Lotfy, M.A. Hegazy, M.R. Rezk, Y.R. Omran, (2014) Novel spectrophotometric methods for simultaneous determination of timolol and dorzolamide in their binary mixture, Spectrochimica Acta Part A: Molecular and Biomolecular Spectroscopy, 126 197-207.

I. Ich, Q2 (R1) (2005) Validation of analytical procedures: text and methodology, in: International Conference on Harmonization, Geneva,.

M. Bahram, (2007) Mean centering of ratio spectra as a new method for determination of rate constants of consecutive reactions, Analytica chimica acta, 603 13-19.

M.M. Abdelrahman, (2013) Simultaneous determination of Cinnarizine and Domperidone by area under curve and dual wavelength spectrophotometric methods, Spectrochimica Acta Part A: Molecular and Biomolecular Spectroscopy, 113 291-296.

P.A. Shah, A.S. Kadikar, R.M. Katira, K.G. Patel, T.R. Gandhi, (2014) Simultaneous determination of brinzolamide and timolol maleate using three different spectrophotometric methods, World J Pharm and Pharm Sci, 2 19551967.

R. Khatun, S.A. Islam, (2014) Development and validation of analytical method for simultaneous estimation of brinzolamide and timolol by HPLC from ophthalmic preparation, International Journal of Pharmaceutical Sciences and Research, 51001.

The United States Pharmacopoeia and National Formulary,United States Pharmacopeia Convention Inc. , Rockville, (2012).

V. MATLAB, 7.10. 0.499 (R2010a), the MathWorks, Inc., Natick, MA, (2010). 


\section{طرائق طيف ضوئية لتحليل خليط ثنائي مكون من البرينزولاميد و التيمولول في الحاله النقيه

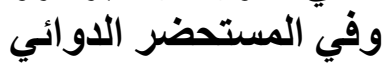 \\ للساده الاكاتره \\ مايا شعبان عبسي * اسر اء ممدوح نور * محمد رفعت الغباشي ** مصطفي عبدالعاطي شحته**

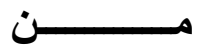 \\ قسم الكيمياء التحليليه ،كليه صيدله ،الجامعه المصريه الروسيهر مانه \\ ق*م الكيمياء التحليليه ،كليه الصيدله ،جامعه القاهره}

الملخص:

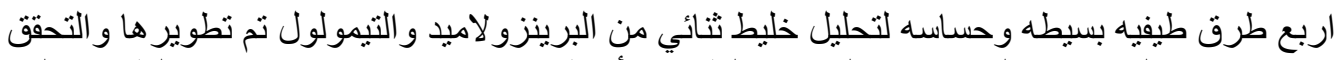

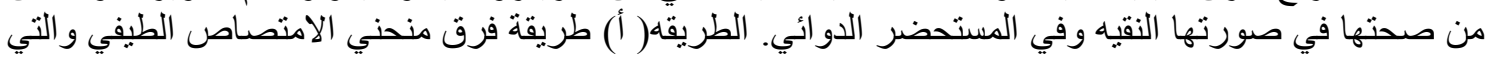

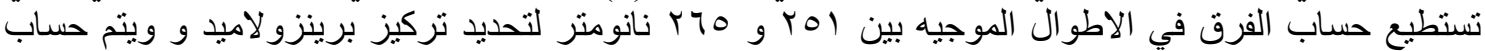

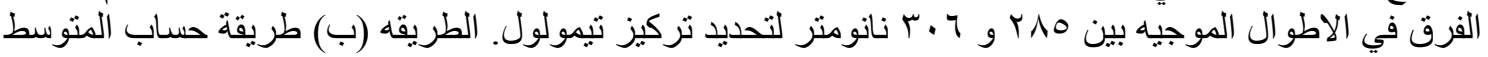

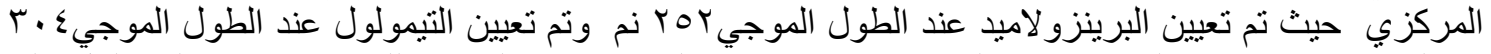

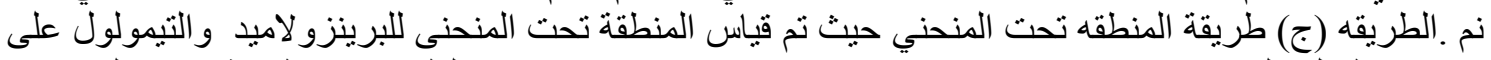

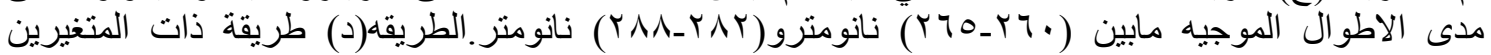

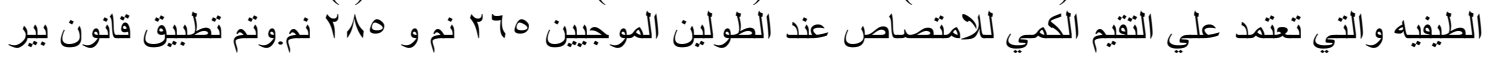

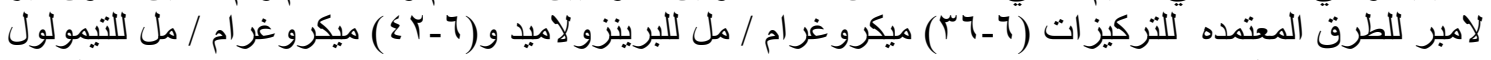

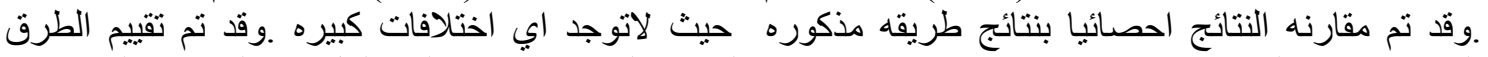

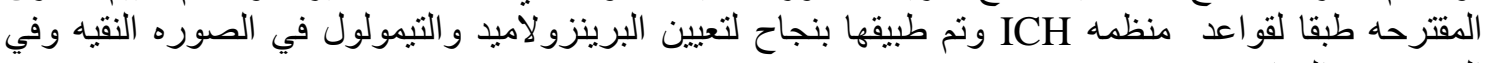
المستحضر الدوائي.

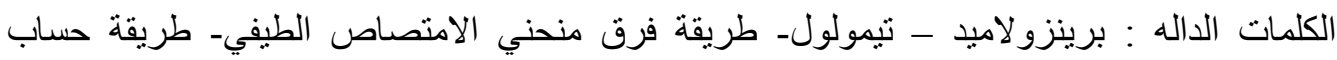

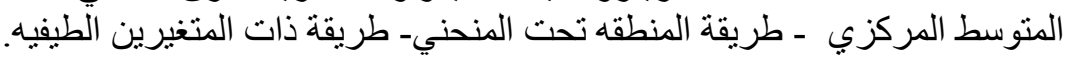

